\title{
Порівняння онкологічних результатів нефректоміі та резекціі нирки у лікуванні хворих із раком нирки стадій T1B TA T2
}

\author{
В. М. Григоренко ${ }^{1}$, А. П. Онищук ${ }^{2}$, М. В. Вікарчук ${ }^{1}$, Р. О. Данилець ${ }^{1}$, А. П. Нестерчук ${ }^{1}$,
} О. О. Банас ${ }^{1}$, Л. В. Перета ${ }^{1}$

${ }^{1}$ Інститут урології НАМН України, м. Київ,

${ }^{2}$ Волинська обласна клінічна лікарня

\section{Comparison of oncological results of nephrectomy and renal resection in treatment of patients with a kidney cancer stages $\mathrm{T} 1 \mathrm{~B}$ and $\mathrm{T} 2$}

\author{
V. M. Grygorenko ${ }^{1}$, A. P. Onyshchuk ${ }^{2}$, M. V. Vikarchuk ${ }^{1}$, R. O. Danylets ${ }^{1}$, A. P. Nesterchuk ${ }^{1}$, \\ O. O. Banas ${ }^{1}$ L. V. Pereta ${ }^{1}$ \\ ${ }^{1}$ Institute of Urology, Kyiv, \\ ${ }^{2}$ Volyhn Regional Clinical Hospital
}

\section{Реферат}

Мета. Продемонструвати можливості органозберігаючого хірургічного лікування у хворих з нирково-клітинним раком (НКР) стадій T1b-T2NOM0 та порівняти онкологічні результати резекції нирки (РН) та нефректомії (НЕ).

Матеріали і методи. 32012 по 2015 р. 3 приводу НКР клінічних стадій Т1b-T2NOMO прооперовано 167 хворих: РН виконана 79 (47,0\%) хворим (1-ша група), НЕ - 88 (53\%) хворим (2-га група).

Результати. Обидві групи статистично не відрізнялись за віком та статтю. В 1-шій групі середній розмір пухлини дорівнював 5,7 см, у 2-гій - 8,7 см (p=0,002). Середній спостереження склав 49,1 міс - у 1-шій групі, 46,9 міс - у 2-гій групі $(\mathrm{p}=0,4)$. Рецидив за час спостереження виявлено у 16 хворих: у 6 (7,6\%) - у 1 -шій групі, у 10 (11,3\%) - у 2 -гій. У $1-$ шій і 2-гій групах 5-річна безрецидивна виживаність становила 93,1 та 90,8\% ( - 89,7 та 90,4\% ( $\mathrm{p=0,929),} \mathrm{5-річна} \mathrm{канцерспецифічна} \mathrm{виживаність} \mathrm{-} \mathrm{91,6} \mathrm{та} \mathrm{89,5 \%} \mathrm{(p=0,414)} \mathrm{відповідно.}$

Висновки. Онкологічні результати РН та НЕ однакові в хірургічному лікуванні НКР стадій T1b-T2NOMO. Основним критерієм для вибору операції з приводу НКР є не розміри пухлини, а особливості ії розташування та кількість залишкової функціональної паренхіми.

Ключові слова: нирково-клітинний рак; резекція нирки.

\section{Abstract}

Objective. To analyze the possibilities of organpreserving surgical treatment in patients, suffering renal-cellular cancer Stages t1b-T2NOM0, and to compare oncological results of renal resection and nephrectomy.

Materials and methods. In 2012 - 2015 yrs in 167 patients, suffering renal-cell cancer of clinical stages t1b-T2NOMO following operations were done: renal resection was performed in 79 (47.0\%) patients (1-st Group), and nephrectomy - in 88 (53\%) patients (2-nd Group).

Results. Both groups are statistically equal in sense of age and gender. In the 1-st Group the average size of the tumor have constituted $5.7 \mathrm{~cm}$, and in $2-\mathrm{nd}-8.7 \mathrm{~cm}(\mathrm{p}=0.002)$. Average duration of observation have constituted $49.1 \mathrm{mo}-$ in the $1-\mathrm{st}$ Group, $46.9 \mathrm{mo}$ - in 2 -nd Group ( $\mathrm{p}=0.4)$. Recurrence through the observation time was revealed in 16 patients: in $6(7.6 \%)-$ in $1-\mathrm{st}$ Group, and in 10 (11.3\%) - in 2-nd. In 1-st and 2-nd Groups a 5-year disease-free survival have constituted 93.1 and $90.8 \%$ $(\mathrm{p}=0.315), 5$-year general survival -89.7 and $90.4 \%(\mathrm{p}=0.929), 5$-year cancer-specific survival -91.6 and $89.5 \%(\mathrm{p}=0.414)$ accordingly.

Conclusion. Oncological results while using renal resection and nephrectomy in surgical treatment of renal-cell cancer Stages $\mathrm{t} 1 \mathrm{~b}-\mathrm{T} 2 \mathrm{NOM} 0$ are equal. The main criteria for the operation choice for renal-cell cancer is not the tumor dimensions, but peculiarities of its placement and the resting parenchyma quantity.

Keywords: renal-cell cancer; renal resection.

За даними Національного канцер-реєстру в Україні в 2015 р. виявлено понад 4500 нових випадків захворювань на НКР, частка яких у структурі онкологічної захворюваності населення склала 3,4\%. 32000 по 2015 р. показник захворюваності на НКР зріс з 8,2 до 12,7 на 100000 населення [1, 2]. Захворюваність на НКР зростає і в більшості країн світу, що пояснюється розширенням використання ультразвукових та рентгенологічних методів обстеження, які дають можливість частіше виявля- ти невеликі безсимптомні пухлини. Тривалий час оптимальним методом лікування локалізованого і місцеворозповсюдженого НКР вважали радикальну НЕ [3], а органозберігаючі операції виконували лише за абсолютними показаннями. В подальшому було продемонстровано одинакові онкологічні результати НЕ та РН при новоутвореннях нирок менше 4 см, завдяки чому показання до органозберігаючих операцій при НКР були розширені [4]. 
Існуючі стандарти лікування містять рекомендацію виконувати РН як метод вибору у лікуванні пухлин нирки стадії Т1а та надавати перевагу органозберігаючим операціям перед НЕ при пухлинах стадії T1b за умов технічної можливості $[5,6]$. Для пухлин стадії Т2 стандартом лікування залишається НЕ, хоча $є$ повідомлення про можливість виконання РН в окремих пацієнтів [7].

У систематичному огляді та метааналізі, опублікованому M. С. Mir і співавторами [8] у 2017 р., що базується на результатах лікування більше 11000 хворих із пухлинами нирки стадій сT1b, Т2 із 23 центрів, визначено, що РН забезпечує адекватний онкологічний контроль і водночас покращує загальну виживаність завдяки збереженню функції нирки.

Переваги РН перед НЕ при пухлинах розміром більше 4 см потребують ретельнішого вивчення [9]. Опубліковані дані свідчать про однакові онкологічні результати PH та HE [10, 11], однак органозберігаючі операції дуже обмежено використовують у лікуванні пухлин нирки стадій Т1b та Т2 [12, 13].

Мета дослідження: продемонструвати можливості органозберігаючого лікування при НКР стадій Т1b та T2NOMO і порівняти онкологічні результати $\mathrm{PH}$ та НE у таких хворих.

\section{Матеріали і методи дослідження}

Ретроспективно оцінено результати хірургічного лікування 168 хворих з НКР клінічних стадій Т1b, Т2NOM0, яким за період з 2012 по 2015 р. виконано РН або НЕ у відділі відновної урології та новітніх технологій Інституту. РН (органозберігаюче лікування) виконана 79 (47,0\%) хворим, у тому числі із лапароскопічного доступу - 19, відкритого (трансабдомінального або люмботомічного) - 60. НЕ виконана 88 (53,0\%) пацієнтам: 49 - лапароскопічна, 39 - відкрита.

Діагноз та клінічну стадію встановлювали за даними комп'ютерної томографії (КТ) або магнітно-резонансної томографії (МРТ) оранів черевної порожнини та заочеревинного простору.

Стадії НКР визначали 3 дотриманням класифікації Міжнародного протиракового союзу за системою TNM 8-го видання [14].

Вибір хірургічної тактики на користь РН або НЕ був мультифакторним, враховували загальний стан, вік хворого, функцію протилежної нирки, супутні захворювання, особливості розташування пухлини по відношенню до ниркового синусу та судин, кількість залишкової паренхіми нирки. Вибір хірургічного доступу (лапароскопічний, трансабдомінальний або люмботомічний) залежав від особливостей локалізації пухлини та досвіду хірурга.

Для статистичної обробки всі дані були внесені в електронні таблиці EXCEL. Аналізували отримані результати з використанням ліцензійних статистичних програм SPSS 18.0 for Windows. Для порівняння вихідних даних хворих та онкологічних результатів використовували критерій Стьюдента. Із Національного канцер-реєстру отримані дані про випадки смерті від НКР. Загальну, канцер-специфічну та безрецидивну виживаність розраховували за методом Каплана-Мейера. Достовірність різниці оцінювали за допомогою log-rank тесту.

\section{Результати}

Обидві групи статистично не відрізнялись за віком та статтю. Права нирка була уражена пухлиною у 54,4\% хворих 1-шої групи та у 48,9\% хворих 2-гої групи. У 2 -гій групі частіше виявляли симптоматичні пухлини, зокрема, гематурію мали 20,5\% хворих. У 2-й групі пухлину, що пальпувалась, мали 25,0\% хворих, у 1-шій групі - 2,5\%. За частотою больового синдрому групи статистично не відрізнялись.

За частотою супутніх захворювань, що потенційно можуть знижувати функцію нирки (цукровий діабет, гіпертонічна хвороба), групи так само статистично не відрізнялись.

Середній максимальний розмір пухлини дорівнював

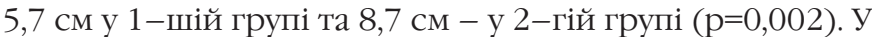
1-шій групі більшість становили хворі з НКР клінічної стадіï T1bNOMO, у 2-гій групі - T2NOMO. Групи хворих не відрізнялись за локалізацією пухлини, однак у 2-гій групі 10 (11,4\%) хворих мали тотальне ураження нирки пухлинним новоутворенням. Також у 2 -гій групі 70,5\% хворих мали переважно інтраренальний характер росту пухлини. У 1-шій групі інтраренальні пухлини були лише у $22,8 \%$ хворих.

За результатами патоморфологічного дослідження у 84,8\% хворих 1-шої групи була стадія рТ1b, у 2-гій групі було приблизно порівну хворих із стадіями рТ1b, pT2a та рТ2b, крім того, у 2 (2,3\%) хворих виявлено пухлинний тромб ниркової вени (стадія рТЗа). Метастазів у регіонарні лімфатичні вузли не виявлено у жодного хворого.

У 1 -шій групі частіше виявляли нетипові форми НКР. Папілярна форма НКР була у $11,4 \%$ хворих 1 -шої групи і у 2,3\% хворих 2 -гої групи $(\mathrm{p}=0,01)$. Крім того, у $1-$ шій групі більшість пухлин були високодиференційованими. У 43,0\% хворих цієї групи і у 26,1\% хворих 2-гої групи ( $\mathrm{p}=0,004)$ виявлено I ступінь диференціації ядер за Фурманом. Клінічна та патоморфологічна характеристика хворих наведена в таблищі.

Середній термін спостереження не відрізнявся в обох групах і дорівнював 49,1 (0,2 - 72,5) міс - у 1-шій групі та $46,9(5,5-72,3)$ міс - у 2 -гій групі $(p=0,4)$. Рецидив за час спостереження виявлено у 16 хворих: у 10 (11,3\%) - у $2-$ гій групі, у 6 (7,6\%) - у 1-шій групі. Із 6 хворих 1-шої групи, у яких розвинувся рецидив НКР, у 5 (6,3\%) була стадія pT1bNOMO, y 1 (1,3\%) - pT2aNOMO. У 2-гій групі серед 10 хворих із рецидивом у $3(3,4 \%)$ була стадія рТ1bNOM0, у 6 $(6,8 \%)$ - pT2aNOMO, у 1 (1,1\%) - pT2bNOMO. У 1-шій та 2гій групах 5-річна безрецидивна виживаність становила 93,1 та 90,8\% (р=0,315) відповідно.

Померли за час спостереження 14 хворих (по 7 в обох групах), у тому числі від НКР та його ускладнень - 11. У 1 -шій групі 4 (5,1\%) хворих, у 2-гій - 7 (7,9\%). У 1-шій та 2-гій групах 5-річна канцерспецифічна виживаність становила 91,6 та 89,5\% (p=0,414) відповідно, 5-річна загальна виживаність 89,7 та 90,4\% (p=0,929) відповідно.

\section{Обговорення}

Проведеним дослідженням отримані дані, які дають підстави стверджувати про однакові онкологічні результати РН або НЕ у хворих з НКР клінічних стадій Т1b та T2NOMO. 


\begin{tabular}{|c|c|c|}
\hline \multirow{2}{*}{ Показник } & \multicolumn{2}{|c|}{ Величина показника в групах } \\
\hline & 1-ша (n=79) & 2 -га $(n=88)$ \\
\hline Середній вік, років & $56,5 \pm 1,4(29-77)$ & $58,0 \pm 1,3(34-79)$ \\
\hline \multicolumn{3}{|l|}{ Стать } \\
\hline чоловіки, абс. (\%) & $48(60,7)$ & $46(52,3)$ \\
\hline жінки, абс. (\%) & $31(39,2)$ & $42(47,7)$ \\
\hline \multicolumn{3}{|l|}{ Симптоми } \\
\hline гематурія, абс. (\%) & $2(2,5)$ & $18(20,5)$ \\
\hline біль, абс.(\%) & $23(29,1)$ & $26(29,5)$ \\
\hline пальпація, абс.(\%) & $2(2,5)$ & $22(25,0)$ \\
\hline \multicolumn{3}{|l|}{ Супутні захворювання } \\
\hline цукровий діабет, абс. (\%) & $8(10,1)$ & $9(10,2)$ \\
\hline гіпертонічна хвороба, абс. (\%) & $33(41,8)$ & $34(38,6)$ \\
\hline Середній розмір пухлини, мм & $56,7 \pm 1,4(41-112)$ & $86,9 \pm 2,9(42-190)$ \\
\hline \multicolumn{3}{|l|}{ Клінічна стадія, абс. (\%) } \\
\hline T1bNOM0 & $66(83,5)$ & $28(31,8)$ \\
\hline T2aNOMO & $10(12,7)$ & $31(35,2)$ \\
\hline T2bNOMO & $3(3,8)$ & $29(33,0)$ \\
\hline \multicolumn{3}{|l|}{ Локалізація } \\
\hline верхній полюс, абс. (\%) & $24(30,4)$ & $25(28,4)$ \\
\hline середній полюс, абс. (\%) & $22(27,8)$ & $24(27,3)$ \\
\hline нижній полюс, абс. (\%) & $33(41,8)$ & $29(33,0)$ \\
\hline тотальне ураження, абс.(\%) & - & $10(11,4)$ \\
\hline Інтраренальний характер росту, абс. (\%) & $18(22,8)$ & $62(70,5)$ \\
\hline \multicolumn{3}{|l|}{ Патоморфологічна стадія, абс.(\%): } \\
\hline рТ1в & $67(84,8)$ & $28(31,8)$ \\
\hline рT2a & $10(12,7)$ & $34(38,6)$ \\
\hline рТ2в & $2(2,5)$ & $24(27,3)$ \\
\hline рТЗа & - & $2(2,3)$ \\
\hline \multicolumn{3}{|l|}{ Патогістологічний висновок } \\
\hline світлоклітинний рак, абс. (\%) & $65(82,3)$ & $83(94,3)$ \\
\hline папілярний рак, абс. (\%) & $9(11,4)$ & $2(2,3)$ \\
\hline інші форми, абс. (\%) & $5(6,3 \%)$ & $3(3,4 \%)$ \\
\hline \multicolumn{3}{|l|}{ Градація за Фурманом, абс. (\%) } \\
\hline І ступінь & $34(43,0)$ & $23(26,1)$ \\
\hline ІІ ступінь & $26(32,9)$ & $46(52,3)$ \\
\hline III - IV ступінь & $6(7,6)$ & $14(15,9)$ \\
\hline
\end{tabular}

Першочерговим завданням хірургічного лікування НКР є радикальне видалення пухлини. Доцільність розширення показань до проведення органозберігаючого лікування НКР за рахунок виконання РН хворим із стадіями T1b та T2N0M0 підтверджено кількома дослідженнями і підсумовано у нещодавно опублікованому метааналізі [8].

Крім того, отримані дослідниками дані вказують на кращу загальну виживаність пацієнтів, яким було виконано РН впродовж тривалого періоду спостереження, завдяки збереженню ниркової функції і, як наслідок, меншій частоті виникнення ниркової недостатності та серцево-судинних захворювань [8].

В даному аспекті цікаво оцінити загальну виживаність хворих у 1-шій та 2-гій групах за триваліший період після операції.

Основним критерієм вибору методу хірургічного лікування НКР є не розмір пухлини, а особливості ії розташування та кількість залишкової функціональної парен- хіми. НЕ виконували переважно у хворих з інтраренальним розташуванням пухлини. Результатом урахування нами фактора розміру пухлини при виборі операції були більший середній розмір пухлини та відповідно більша частка хворих, що мали стадію Т2 у 2-гій групі. 3 набуттям досвіду хірургами у дедалі більшого числа хворих із пухлинами нирки великих розмірів буде змога проводити органозберігаюче лікування.

\section{Висновки}

1. РН та НЕ мають однакові онкологічні результати в хірургічному лікуванні пухлин нирки стадій Т1b та T2NOMO.

2. Основним критерієм вибору методу оперативного втручання з приводу НКР є не розмір пухлини, а особливості їі розташування, кількість залишкової функціональної паренхіми та наявність супутньої патології, що може призвести до розвитку ниркової недостатності. 


\section{References}

1. Fedorenko ZP, Goulak LO, Michailovich YY, et al. Cancer in Ukraine, 2015-2016. Bulletin of national cancer registry of Ukraine. Kyiv, 2017;18. 86 p.

2. Fedorenko ZP, Goulak LO, Gorokh YL, et al. Cancer in Ukraine, 1998-2000. Bulletin of national cancer registry of Ukraine. Kyiv, 2001;2.120p.

3. Robson CJ, Churchill BM, Anderson W. The results of radical nephrectomy for renal cell carcinoma. J Urol. 1969;101:297.

4. Uzzo RG, Novick AC. Nephron sparing surgery for renal tumors: indications, techniques and outcomes. J Urol. 2001;166:6-18.

5. Ljungberg B, Bensalah K, Canfield S, Dabestani S, Hofmann F, Hora M, et al. EAU guidelines on renal cell carcinoma: 2014 update. Eur Urol. 2015;67:913-24. doi: 10.1016/j.eururo.2015.01.005.

6. Campbell SC, Novick AC, Belldegrun A, Blute M, Chow G, Derweesh $\mathrm{IH}$, et al. Guideline for management of the clinical T1 renal mass. J Urol. 2009;182:1271-9. doi: 10.1016/j.juro.2009.07.004.

7. Lee HJ, Liss MA, Derweesh IH. Outcomes of partial nephrectomy for clinical T1b and T2 renal tumors. Curr Opin Urol. 2014;24:448-52. doi: 10.1097/MOU.0000000000000081

8. Mir MC, Derweesh I, PorpigliaF, Zargar H, Mottrie A, Autorino R. Partial Nephrectomy Versus Radical Nephrectomy for Clinical T1b and T2 Renal Tumors: A Systematic Review and Meta-analysis of Comparative Studies. Eur Urol. 2017;71:606-17. doi: 10.1016/j.eururo.2016.08.060.
9. Weight CJ, Miller DC, Campbell SC, Derweesh IH, Lane BR, Messing EM. The management of a clinical T1b renal tumor in the presence of a normal contralateral kidney. J Urol. 2013;189:1198-202. doi: 10.1016/j.juro.2013.01.030.

10. Cre'pel M, Jeldres C, Perrotte P, Capitanio U, Isbarn H, Shariat SF, et al. Nephron-sparing surgery is equally effective to radical nephrectomy for T1BN0M0 renal cell carcinoma: a population-based assessment. Urology. 2010;75:271-5. doi: 10.1016/j.urology.2009.04.098.

11. Badalato GM, Kates M, Wisnivesky JP, Choudhury AR, McKiernan JM. Survival after partial and radical nephrectomy for the treatment of stage T1bN0M0 renal cell carcinoma (RCC) in the USA: a propensity scoring approach. BJU Int. 2012;109:1457-62. doi: 10.1111/j.1464 410X.2011.10597.x

12. Hadjipavlou M, Khan F, Fowler S, Joyce A, Keeley FX, Sriprasad S. Partial vs radical nephrectomy for T1 renal tumours: an analysis from the British Association of Urological Surgeons Nephrectomy Audit. BJU Int. 2016;117:62-71.

13. Meskawi M, Becker A, Bianchi M, et al. Partial and radical nephrectomy provide comparable long-term cancer control for $\mathrm{T} 1 \mathrm{~b}$ renal cell carcinoma. Int J Urol. 2014;21:122-8. doi: 10.1111/bju.13114.

14. Brierley JD, Gospodarowicz MK, Wittekind C. TNM classification of malignant tumors. UICC International Union Against Cancer. 8th edn. Wiley-Blackwell; 2017. 241p. 